\title{
Supraventricular tachycardia caused by nebulised ipratropium bromide
}

\author{
B R O'DRISCOLL
}

From the Department of Thoracic Medicine, Wythenshawe Hospital, Manchester

ABSTRACT A 71 year old patient developed a supraventricular tachycardia after the administration of nebulised ipratropium bromide.

Nebulised beta agonists may cause tachycardia and arrhythmias in sensitive individuals, but a search of published papers yielded no case reports of cardiac arrhythmias caused by nebulised ipratropium bromide.

\section{Case report}

A 71 year old woman with steroid dependent late onset asthma (peak flow $140 \mathrm{l} / \mathrm{min}, \mathrm{FEV}_{1} 0.5 \mathrm{l}$, FVC 0.95 $1, \mathrm{PaO}_{2}$ $11.2 \mathrm{kPa} ; \mathrm{PaCO}_{2} 5.3 \mathrm{kPa}$ ) was referred for consideration of domiciliary nebuliser treatment. Her usual medications were prednisolone $10 \mathrm{mg}$ daily, inhaled beclomethasone $2 \mathrm{mg}$ daily, inhaled salbutamol $800 \mu \mathrm{g}$ daily, inhaled ipratropium bromide $160 \mu \mathrm{g}$ daily, and slow release theophylline $400 \mathrm{mg}$ at bedtime. She also took amiloride $5 \mathrm{mg}$ and hydrochlorothiazide $50 \mathrm{mg}$ daily for mild ankle oedema. She was given a test dose of ipratropium bromide $(0.5 \mathrm{mg}$ of preservative free solution in $2 \mathrm{ml}$ saline by nebuliser) in the outpatient clinic with no adverse effects, so she was prescribed $0.5 \mathrm{mg}$ nebulised ipratropium bromide to be taken four times a day at home. She reattended the following day because severe breathlessness began a few minutes after completion of each dose and lasted two to three hours. She was too distressed to record her peak flow rate. She was admitted for further assessment.

Her initial treatment was $5 \mathrm{mg}$ salbutamol nebuliser solution by inhalation six hourly. She complained of episodic breathlessness with this treatment, however, despite a moderate rise in her peak flow. An electrocardiogram recorded during such an episode showed the development of atrial fibrillation ( 152 beats $/ \mathrm{min}$ ). Her baseline ECG showed sinus rhythm (104 beats/min with three supraventricular ectopic beats/min), right atrial hypertrophy, and minor repolarisation changes. Urea and electrolyte concentrations were normal and the morning serum theophylline concentration was $99 \mu \mathrm{mol} / 1$ (target range 55-110). Her treatment was changed to salbutamol (metered dose inhaler, $200 \mu \mathrm{g}$ six hourly) and she had no further episodes of breathlessness or tachycardia.

After giving her informed consent she was given various doses of salbutamol and ipratropium bromide in a single blind fashion on separate mornings with peak flow and ECG

Address for correspondence: Dr B R O'Driscoll, Chest Clinic, Wythenshawe Hospital, Manchester M23 9LT. (Reprints will not be available.)

Accepted 2 December 1988

\begin{tabular}{|c|c|c|c|}
\hline Medication & $\begin{array}{l}\text { HR (beats } / \mathrm{min}) \\
\text { cardiac rhythm }\end{array}$ & $\begin{array}{l}P E F \\
(l / \min )\end{array}$ & $\begin{array}{l}\text { Subjective } \\
\text { response }\end{array}$ \\
\hline $\begin{array}{l}\text { Baseline } \\
\text { Salbutamol inhaler }\end{array}$ & $\begin{array}{l}116, \text { sinus } \\
104, \text { sinus }\end{array}$ & $\begin{array}{r}90 \\
105\end{array}$ & $\overline{\text { Slight benefit }}$ \\
\hline $\begin{array}{l}\text { Salbutamol } \\
\text { nebuliser } 5 \mathrm{mg}\end{array}$ & $\begin{array}{l}\text { 152, atrial fibrillation } \\
\text { (lasted } 20 \mathrm{~min} \text { ) }\end{array}$ & 160 & Felt breathless \\
\hline $\begin{array}{l}\text { IB inhaler } 80 \mu \mathrm{g} \\
\text { IB nebuliser } \\
500 \mu \mathrm{g}\end{array}$ & $\begin{array}{l}112, \text { sinus } \\
200, \text { supra-ventricular } \\
\text { tachycardia (lasted } \\
45 \text { min) }\end{array}$ & $\begin{array}{l}100 \\
140\end{array}$ & $\begin{array}{l}\text { Slight benefit } \\
\text { Felt short of } \\
\text { breath, } \\
\text { lightheaded }\end{array}$ \\
\hline
\end{tabular}

monitoring. She remained in sinus rhythm after salbutamol $400 \mu \mathrm{g}$ and ipratropium bromide $80 \mu \mathrm{g}$, both given by metered dose inhaler, but developed atrial fibrillation after nebulised salbutamol $(5 \mathrm{mg})$ and supraventricular tachycardia after nebulised ipratropium bromide (table).

\section{Discussion}

Previous laboratory studies have suggested that inhaled ipratropium bromide does not cause any increase in heart rate. ' Nebulised ipratropium bromide $(0.5 \mathrm{mg})$ had no effect on the heart rate of seven asthmatic and 13 bronchitic patients we have studied (personal observation). The Committee on Safety of Medicines is aware of only two cases of tachycardia that might have been caused by inhaled ipratropium bromide (personal communication), and the manufacturers of ipratropium bromide (Boehringer Ingelheim) know of nine possible cases, which have been poorly documented. Although very little of the drug is absorbed after its administration by inhalation, the drug is used parenterally in some countries for its atropine like effect on the heart. The present patient would appear to have very sensitive cardiac conducting tissues and to have absorbed sufficient ipratropium bromide (and salbutamol) to produce arrhythmia. Nebulised ipratropium bromide should be given with caution (and with cardiac monitoring) to patients who are known to be at risk of cardiac arrhythmias.

I would like to thank Dr A Bernstein for permission to report these observations on his patient.

\section{Reference}

1 Chapman KR, Smith DL, Rebuck AS, Leenen FHH. Haemodynamic effects of inhaled ipratropium bromide alone and combined with an inhaled beta ${ }_{2}$-agonist. Am Rev Respir Dis 1985;132:845-7. 